Article

\title{
Effects of Thermal Discharge from Coastal Nuclear Power Plants and Thermal Power Plants on the Thermocline Characteristics in Sea Areas with Different Tidal Dynamics
}

\author{
Faming Huang $1, *$, Jie Lin $1,2,3, * \mathbb{D}$ and Binxin Zheng 1 \\ 1 Third Institute of Oceanography, Ministry of Natural Resources, Xiamen 361005, China; \\ zhengbinxin@tio.org.cn \\ 2 School of Geographic and Oceanographic Sciences, Nanjing University, Nanjing 210093, China \\ 3 Collaborative Innovation Center of South China Sea Studies, Nanjing University, Nanjing 210093, China \\ * Correspondence: huangfaming@tio.org.cn (F.H.); linjie@tio.org.cn (J.L.)
}

Received: 2 October 2019; Accepted: 3 December 2019; Published: 6 December 2019

\begin{abstract}
The thermal discharge from coastal nuclear power plants and thermal power plants (CNATPP) not only increases the water temperature, but it also stratifies the seawater. Comprehending the characteristics of stratification that is caused by thermal discharge constitutes the basis for developing a comprehensive understanding of how thermal discharge affects marine organisms. The spatial and temporal characteristics of seawater stratification induced by thermal discharge were analyzed on the basis of measured data while using two study areas with different tidal dynamics as examples. The results showed the following. (1) Thermal discharge influenced the area within $3 \mathrm{~km}$ of the outlet. (2) In the East China Sea (which has strong tidal dynamics), the most significant stratification occurred $0.5 \mathrm{~km}-1.0 \mathrm{~km}$ from the outlet; however, in the South China Sea (which has weak tidal dynamics), the degree of stratification decreased with increasing distance from the outlet. (3) In the East China Sea (i.e., strong tidal dynamics), the depth of the thermocline during ebb tide gradually moved upward, while that during flood tide gradually moved downward, and the opposite was observed in the South China Sea (i.e., weak tidal dynamics). Finally, (4) the thermocline that was caused by thermal discharge mostly occurred at water depths above $7 \mathrm{~m}$.
\end{abstract}

Keywords: thermal discharge; stratification; coastal nuclear power plants and thermal power plants; tidal dynamic

\section{Introduction}

Most previous studies have shown that the thermal discharge from coastal nuclear power plants and thermal power plants (CNATPP) has a negative impact on the abundance and community structure of phytoplankton [1-4], zooplankton [5-7], macrobenthic animals [8,9], and swimming animals [5,10-12], as well as their habitats [13]. The impact of this thermal discharge on aquatic ecosystems has become an important issue in the field of marine and environmental protection [14]. Moreover, the thermal pollution that is caused by thermal discharge has become one of the major environmental problems facing nuclear power construction in China [15].

The thermal discharge of CNATPP affects marine organisms in two main ways. First, the increase in seawater temperature directly affects the environmental temperature of marine organisms. Previous studies on the impacts of thermal discharge on marine organisms mainly focused on analyzing the effects of increased seawater temperature that are caused by thermal discharge on marine organisms. Zeng [16], Poornima [17], and Han [18] evaluated different seawater temperature conditions in the 
laboratory and evaluated the products of seawater temperature increases on the growth of chlorophyll a, macrobenthic animals, and swimming animals. Second, the increase in seawater temperature causes seawater to stratify, which influences the foraging environment of marine organisms. Some studies have suggested that a water temperature increase exceeding $1.5^{\circ} \mathrm{C}$ might induce stratification [16]. Unfortunately, the temperature increase at the thermal discharge outlet of CNATPP is far greater than $1.5^{\circ} \mathrm{C}$; thus, such discharge is likely to cause the stratification of seawater. Yin [19] and Lin et al. [20], who utilized field observation data, and Zhang et al. [21], Wu and Zhu [22], Cui [23], Zhu [24], and Zhang [25], who employed the Estuarine, Coastal, and Ocean Modeling System with Sediment (ECOMSED) and Finite Volume Coastal Ocean Model (FVCOM), found that the thermal discharge from CNATPP induces stratification in the surrounding outlet. Raithby et al. [26] and Salgueiro et al. [27] focused their investigations on the stratification characteristics in lakes based on various models. In addition, Vinnå et al. [28] and Kirillin et al. [29] believed that thermal discharge could not only strengthen stratification, but also prolong the stratification period within a lake, in addition to inducing stratification. Roenunich and MdGoWan [30] and Zeng [16] found that seawater stratification weakens wind-driven upwelling, negatively influencing vertical nutrient exchange and phytoplankton and zooplankton growth. Based on research on the Ningde Nuclear Power Plant, Lin et al. [20] found that the elevated temperature caused by thermal discharge from the power plant affected the growth of macrobenthos in the study area by significantly affecting the abundance and community structure of the phytoplankton and zooplankton therein. However, few studies have evaluated the effects of stratification that are induced by thermal discharge on marine organisms.

Comprehending the characteristics of stratification caused by thermal discharge from CNATPP constitutes the basis for developing a comprehensive understanding of how thermal discharge affects marine organisms. Solar radiation, air temperature, wind speed, and water density are included as the factors that influence the stratification of water temperature [31]. A large-scale surface wind stress curl, geostrophic flow, and propagating waves influence the thermocline in the sea [32]. For example, under the influence of the northerly monsoon in winter, heat exchange and evaporation aggravate the loss of heat from the ocean and increase the mixing of eddies and convection, which can evenly distribute the water temperature in the vertical direction and weaken any present stratification [33]. To date, research on stratification that is caused by thermal discharge from CNATPP has shown the following: (1) The study of Zhou [34] in Daya Bay and the study of Suh [35] in Chonsu Bay indicated that warm water tended to diffuse on the surface after being discharged from the outlet; afterwards, stratification was obvious. However, with the diffusion of warm water farther from the outlet, the vertical temperature of the water column became more evenly distributed; that is, the stratification phenomenon became less obvious. However, Zhang [25] investigated Bohai Bay and found that the stratification in the shallow water near the outlet was weaker than that in the deep water somewhat far from the outlet. The report by $\mathrm{Wu}$ and $\mathrm{Zhu}$ [22] regarding the Yangtse River indicated that stratification occurs from the shore close to the outlet to a water depth of $3 \mathrm{~m}$. However, the spatial extent from the outlet to which the thermal discharge from CNATPP can induce stratification has not been thoroughly studied. (2) Suh et al. [35] observed stratification in the upper layer (above a water depth of $7 \mathrm{~m}$ ) in Chonsu Bay, Korea, while Wang et al. [36] found stratification above a water depth of $5 \mathrm{~m}$ in the Yellow Sea. A study by Cui [23] in the South China Sea found that the diffusion of warm water mainly occurred in the upper half of the total water depth $(0.5 \mathrm{~h})$; in contrast, Zhang et al. [21] investigated the Bohai Sea and found that vertical stratification appeared in the upper $1 / 5$ of the total water depth $(0.2 \mathrm{~h})$. The study by Lin et al. [20] in the East China Sea indicated that most of the stratification emerged in the upper water layers during the flood tide (from ebb slack to maximum flood), while most of the stratification emerged in the lower water layers during the ebb tide (from flood slack to maximum ebb). However, the depth extent of stratification that is induced by thermal discharge from CNATPP has not been studied. (3) Tang et al. [37] found that thermal discharge had the greatest impact on sea surface temperature (SST) in summer and the smallest impact in winter. Zhu [24] believed that the vertical temperature difference of seawater in the neap tide period was higher than that in the spring tide 
period. However, the temporal variation in stratification patterns that is caused by thermal discharge from CNATPP during different tide times has not been investigated.

In this paper, we used two study areas with different tidal dynamics as examples, and we used the measured vertical seawater temperature data to analyze the spatial and temporal characteristics of seawater stratification that are caused by thermal discharge from CNATPP.

Salinity and temperature are two important factors that could induce seawater stratification. A salinity survey of four stations (two within $1 \mathrm{~km}$ away from the outlet as the affected stations and two outside $6 \mathrm{~km}$ away from the outlet as the control stations) in Ningde nuclear power station have been done in autumn, winter, spring, and summer during 2013-2014. The average salinity difference between the surface and bottom layers of in the two affected stations were 0.096 and 0.049 , respectively, and those of the control stations were 0.013 and 0.181 . There were no significant difference between affected stations and control stations. Additionally, salinity differences between the surface and bottom layers in all stations could not reach critical thermocline salinity of $0.1 \mathrm{~m}$. Therefore, the effect of thermal discharge on seawater salinity is very little and thermal discharge could not induce salinity stratification. This conclusion is consistent with the results of Tang et al. [38]. Therefore, only temperature stratification that was caused by thermal discharge was involved in this study.

\section{Materials and Methods}

\subsection{Study Area and Sites}

Two research areas were selected in this study (Figure 1). The first study area (ND), which is adjacent to the outlet of the Ningde Nuclear Power Plant, is located on northwestern Yushan Island in Ningde, Fujian Province, China. This area has a subtropical oceanic climate and the mean annual temperature is $18.7^{\circ} \mathrm{C}$. The duration of the semidiurnal tides in the area near the outfall is regular and the mean tidal range is $4.32 \mathrm{~m}$. From June 2015 to July 2016, the plant consisted of three units, each with an installed capacity of $1000 \mathrm{MW}$. The plant uses seawater as a coolant at a designed flow rate of $172.5 \mathrm{~m}^{3} \mathrm{~s}^{-1}$ and the cooling water is discharged at the surface into the East China Sea. The temperature of the cooling water in the outlet is $8.35^{\circ} \mathrm{C}$ higher than that of the water in the inlet. The other study area (FCG), which is adjacent to the outlet of the Fangchenggang Nuclear Power Plant, is located north of Beibu Bay, Guangxi Province, China. This area has a south subtropical monsoon climate and the mean annual temperature is $22.2^{\circ} \mathrm{C}$. Mixed tides dominated by diurnal tides and the mean tidal range being $2.77 \mathrm{~m}$ are the main tidal characteristics in the study area near the outfall. After October 2016, the plant consisted of two units, each with an installed capacity of $1000 \mathrm{MW}$. The plant uses seawater as a coolant at a designed flow rate of $123 \mathrm{~m}^{3} \mathrm{~s}^{-1}$, and the cooling water is discharged on the surface (6 $\mathrm{km}$ from the shore), whereupon it is discharged into the South China Sea. The temperature of the cooling water in the outlet is $7.5^{\circ} \mathrm{C}$ higher than that of the water in the inlet. 

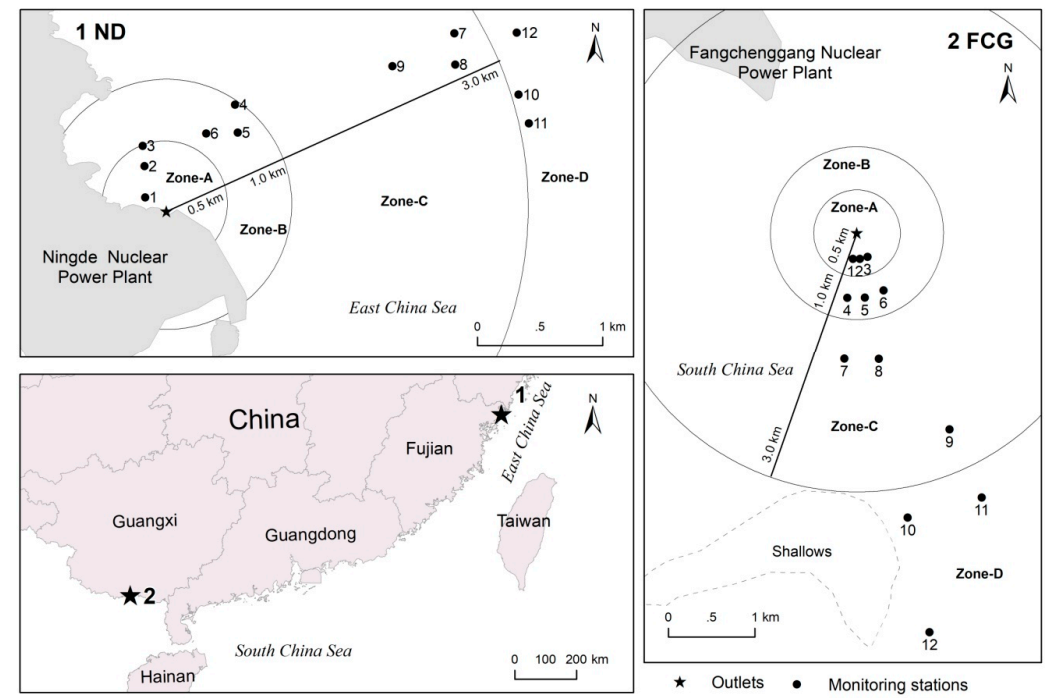

Figure 1. Distribution of the research areas and locations of the sampling stations.

\subsection{Sampling Methods}

Three groups of stations were established at different distances from the outlet to obtain the vertical temperature in the seawater column affected by thermal discharge: $0 \mathrm{~km}-0.5 \mathrm{~km}$ (Zone-A), $0.5 \mathrm{~km}-1.0 \mathrm{~km}$ (Zone-B), $1.0 \mathrm{~km}-3.0 \mathrm{~km}$ (Zone-C) and $3.0 \mathrm{~km}$ from the outlet (Zone-D). Stations 1 3 were located in Zone-A, Stations 4 6 were located in Zone-B, Stations 7 9 were located in Zone-C, and Stations 10 12 were located in Zone-D. Water temperature measurements were collected at 12 stations at $0.5 \mathrm{~m}, 1 / 5$ of the water depth $(0.2 \mathrm{~h}), 2 / 5$ of the water depth $(0.4 \mathrm{~h}), 3 / 5$ of the water depth $(0.6 \mathrm{~h}), 4 / 5$ of the water depth $(0.8 \mathrm{~h})$, and $0.5 \mathrm{~m}$ above the seafloor at flood slack, maximum ebb, ebb slack, and maximum flood. The measurement time at ND was June 5, 2016 (spring tide), and that at FCG was August 11, 2018 (spring tide).

\subsection{Data Analysis}

The difference between the SST and sea bottom temperature (SBT) per unit depth (DTPD) was introduced for measuring the temperature differential between the surface and the bottom of the seawater column without considering the water depth as a factor:

$$
\mathrm{DTPD}=(\mathrm{SST}-\mathrm{SBT}) / \mathrm{h}
$$

where the units of DTPD are ${ }^{\circ} \mathrm{C} \mathrm{m}^{-1}$; the units of SST and SBT are both ${ }^{\circ} \mathrm{C}$; and, $\mathrm{h}$ is the water depth with a unit of $\mathrm{m}$.

\section{Results}

\subsection{Differences between the SST and SBT}

The SSTs and SBTs of the four groups in the ND decreased with increasing distance from the outlet, as shown in Figure 2a. Except for the ebb slack of Zone-A, the temperature differences between the SSTs and SBTs of Zone-A and Zone-D were not significant at other times; in contrast, the temperature differences between the SSTs and SBTs of Zone-B and Zone-C were large. The SSTs and SBTs of the four groups were higher at ebb slack and lower at flood slack and maximum flood with regard to different tidal times.

As shown in Figure 2d, the SSTs and SBTs of the four groups in the FCG decreased with an increasing distance from the outlet. Except for the ebb slack, the SSTs of the four groups were larger than the SBTs of any group at any other time. The temperature differences between the SSTs and SBTs reached a maximum of $2.79{ }^{\circ} \mathrm{C}$ and a minimum of $1.11^{\circ} \mathrm{C}$ during flood slack, a maximum of $4.37^{\circ} \mathrm{C}$ 
and a minimum of $0.52{ }^{\circ} \mathrm{C}$ during maximum ebb, a maximum of $4.25^{\circ} \mathrm{C}$ and a minimum of $0.33^{\circ} \mathrm{C}$ during ebb slack, and a maximum of $3.16^{\circ} \mathrm{C}$ and a minimum of $0.43^{\circ} \mathrm{C}$ during maximum flood. The SSTs and SBTs of the four groups were higher at ebb slack and lower at flood slack and maximum flood with regard to different tidal times.
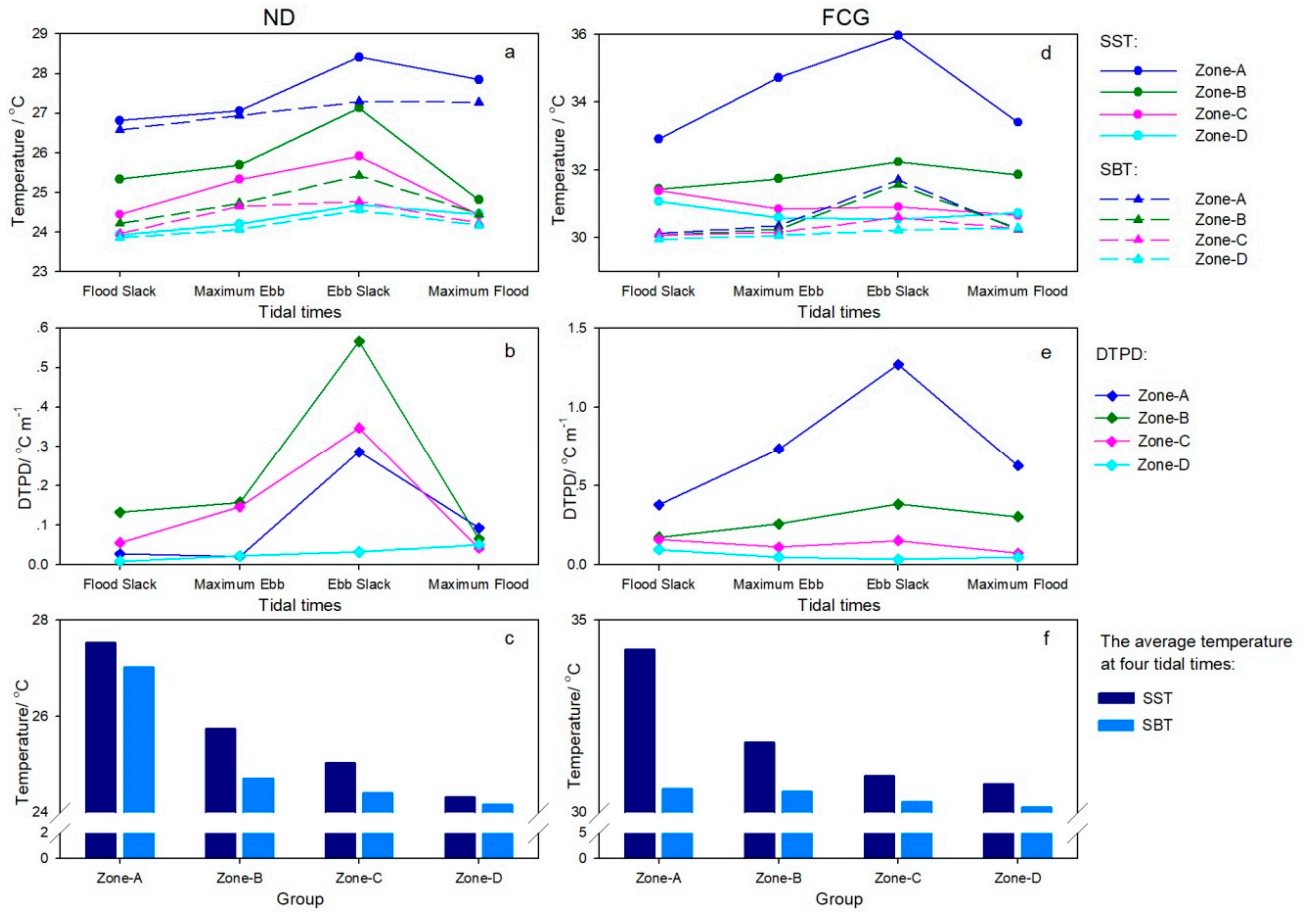

Figure 2. Comparison between the sea surface temperature (SSTs) and sea bottom temperatures (SBTs) of the two study areas among the four zones at the four tidal times. $((\mathbf{a}, \mathbf{d})$ describe the SSTs and SBTs in the four zones at four tidal times in the first study area (ND) and other study area (FCG), respectively; (b,e) describe the difference between the SST and SBT per unit depths (DTPDs) in the four zones at four tidal times in the ND and FCG, respectively; $(\mathbf{c}, \mathbf{f})$ describe the average temperature differences between the SSTs and SBTs in the four zones in the ND and FCG, respectively).

According to Figure $2 b$, the DTPDs at the four tidal times in the ND decreased in the following order: Zone-B > Zone-C > Zone-A > Zone-D. At different tidal times, except for Zone-D, the change in the DTPDs was not obvious; in the other three groups, the maximum DTPDs appeared at ebb slack, while the minimum DTPDs appeared at flood slack and maximum flood.

According to Figure 2e, the DTPDs at the four tidal times in the FCG decreased in the following order: Zone-A > Zone-B $>$ Zone-C $>$ Zone-D. The DTPDs decreased with increasing distance from the outlet. At different tidal times, except for Zone-C and Zone-D, the change in the DTPDs was not obvious; in Zone-A and Zone-B, the maximum DTPDs appeared at ebb slack, while the minimum DTPDs appeared at flood slack and maximum flood.

The SSTs and SBTs in the ND decreased with increasing distance from the outlet based on the average temperatures of the different groups at the four tidal times (Figure 2c). The SSTs were slightly larger than the SBTs in Zone-A and Zone-D, and the SSTs were significantly larger than the SBTs in Zone-A and Zone-D.

Similarly, the SSTs and SBTs in the FCG also decreased with increasing distance from the outlet based on the average temperatures of the different groups at the four tidal times (Figure 2f). However, the decrease in the SSTs was relatively larger than that in the SBTs. In any group, the SSTs were much larger than the SBTs, and the temperature differences were the greatest close to the outlet. 


\subsection{Where Stratification Occurred}

Figure 3 and Table 1 show the seawater temperatures and temperature differences at the four tidal times in the six depth layers in the four zones in the ND and FCG.

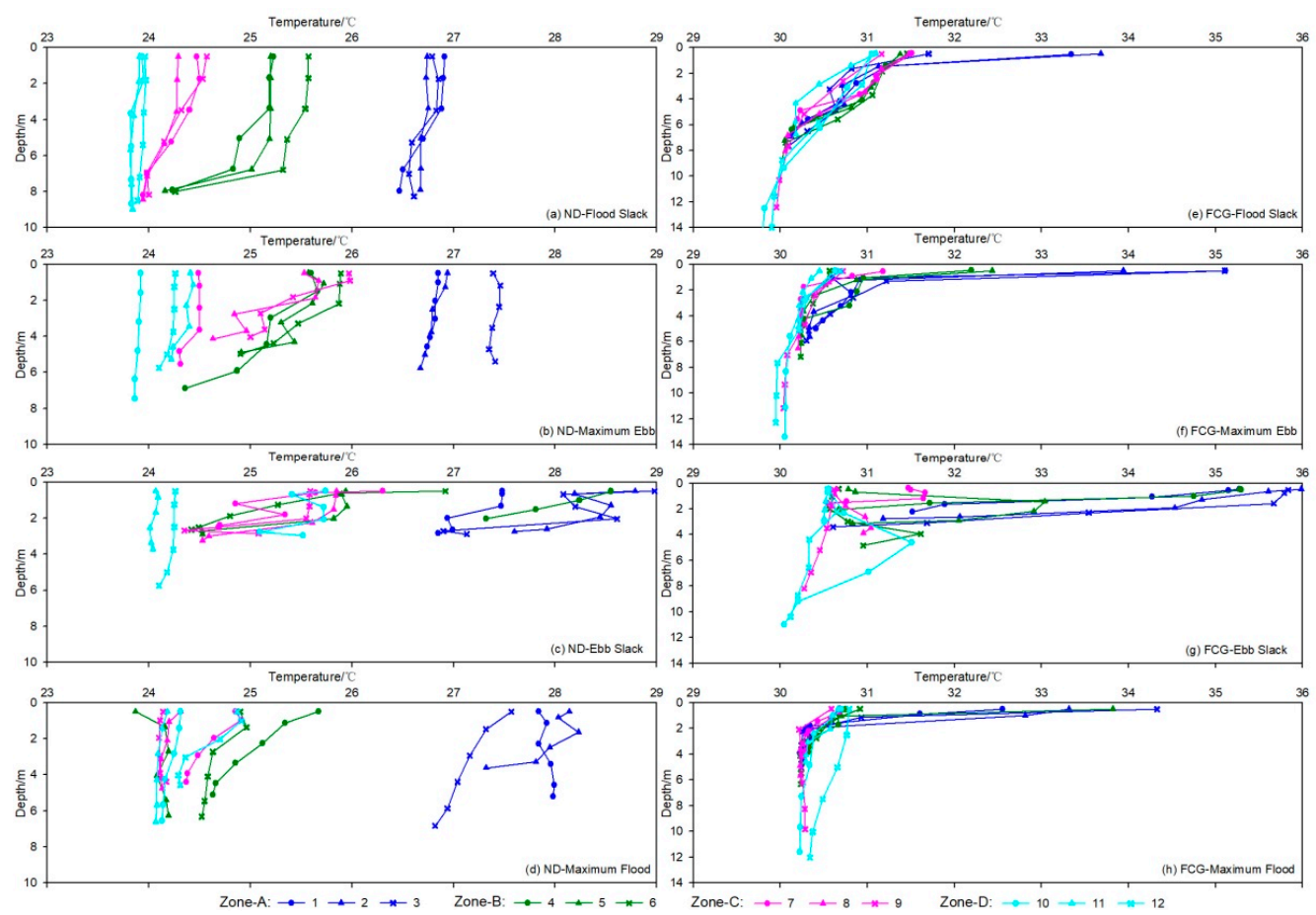

Figure 3. Seawater temperatures at the four tidal times in the six depth layers in the four zones in the ND and FCG. ( (a-d) describe the seawater temperatures in the six depth layers in the four zones in the ND at flood slack, maximum ebb, ebb slack, and maximum flood, respectively; and, (e-h) describe the seawater temperatures in the six depth layers in the four zones in the FCG at flood slack, maximum ebb, ebb slack, and maximum flood, respectively).

Table 1. The temperature differences between different water layers per unit depth in ND and FCG.

\begin{tabular}{|c|c|c|c|c|c|c|c|c|c|c|c|c|}
\hline \multirow[b]{2}{*}{ Period } & \multirow{2}{*}{ Zone } & \multirow[b]{2}{*}{ Station No. } & \multicolumn{5}{|c|}{$\begin{array}{l}\text { Temperature Differences Per Unit Depth in the } \\
\qquad N D\left({ }^{\circ} \mathrm{C} \mathrm{m}^{-1}\right)\end{array}$} & \multicolumn{5}{|c|}{$\begin{array}{l}\text { Temperature Differences Per Unit Depth in the } \\
\text { FCG }\left({ }^{\circ} \mathrm{C} \mathrm{m}^{-1}\right)\end{array}$} \\
\hline & & & $\begin{array}{c}0.5 \\
\mathrm{~m}^{-1} / 5 \\
\mathrm{~h}\end{array}$ & $\begin{array}{c}1 / 5 \\
h^{-2} / 5 h\end{array}$ & $\begin{array}{c}2 / 5 \\
h^{-3} / 5 h\end{array}$ & $\begin{array}{c}3 / 5 \\
\mathrm{~h}^{-4} / 5 \mathrm{~h}\end{array}$ & $\begin{array}{c}4 / 5 \\
\mathrm{~h}^{-0.5} \\
\mathrm{~m} \text { up }\end{array}$ & $\begin{array}{c}0.5 \\
\mathrm{~m}^{-1 / 5} \\
\mathrm{~h}\end{array}$ & $\begin{array}{c}1 / 5 \\
h^{-2} / 5 h\end{array}$ & $\begin{array}{c}2 / 5 \\
h^{-3} / 5 h\end{array}$ & $\begin{array}{c}3 / 5 \\
\mathrm{~h}^{-4} / 5 \mathrm{~h}\end{array}$ & $\begin{array}{c}4 / 5 \\
h^{-0.5} \\
\text { m up }\end{array}$ \\
\hline \multirow{12}{*}{ Flood Slack } & \multirow{3}{*}{ Zone-A } & 1 & 0.01 & 0.01 & 0.11 & 0.12 & 0.03 & $2.31^{1}$ & 0.26 & 0.14 & 0.26 & 0.18 \\
\hline & & 2 & 0.01 & -0.01 & 0.04 & 0.00 & 0.01 & 2.63 & 0.28 & -0.02 & 0.33 & 0.13 \\
\hline & & 3 & -0.05 & 0.01 & 0.14 & 0.02 & -0.04 & 0.77 & 0.16 & -0.04 & 0.20 & 0.19 \\
\hline & \multirow{3}{*}{ Zone-B } & 4 & 0.03 & 0.00 & 0.18 & 0.04 & 0.51 & 0.31 & 0.10 & 0.10 & 0.38 & 0.31 \\
\hline & & 5 & 0.00 & 0.00 & 0.01 & 0.11 & 0.71 & 0.18 & 0.09 & 0.14 & 0.43 & 0.10 \\
\hline & & 6 & 0.00 & 0.02 & 0.11 & 0.02 & 0.88 & 0.20 & 0.06 & 0.21 & 0.33 & 0.03 \\
\hline & \multirow{3}{*}{ Zone-C } & 7 & -0.02 & 0.06 & 0.10 & 0.14 & 0.03 & 0.24 & -0.04 & 0.17 & 0.54 & 0.05 \\
\hline & & 8 & 0.01 & 0.01 & 0.07 & 0.10 & 0.03 & 0.28 & 0.11 & 0.31 & 0.21 & 0.03 \\
\hline & & 9 & 0.03 & 0.12 & 0.10 & 0.10 & -0.02 & 0.21 & 0.17 & 0.07 & 0.04 & 0.02 \\
\hline & \multirow{3}{*}{ Zone-D } & 10 & -0.01 & 0.07 & -0.01 & 0.00 & 0.00 & 0.11 & 0.10 & 0.13 & 0.07 & 0.01 \\
\hline & & 11 & 0.01 & 0.03 & 0.02 & -0.01 & -0.01 & 0.31 & 0.26 & 0.18 & 0.00 & 0.00 \\
\hline & & 12 & -0.01 & 0.01 & 0.01 & 0.02 & 0.02 & 0.05 & 0.17 & 0.14 & 0.03 & 0.01 \\
\hline \multirow{12}{*}{ Ebb Maximum } & \multirow{3}{*}{ Zone-A } & 1 & 0.00 & 0.03 & 0.00 & 0.05 & 0.06 & 7.47 & -0.20 & 0.11 & 0.19 & 0.13 \\
\hline & & 2 & 0.03 & 0.10 & 0.01 & 0.05 & 0.07 & 4.01 & 0.08 & 0.34 & 0.04 & -0.02 \\
\hline & & 3 & -0.10 & 0.01 & 0.06 & 0.03 & -0.09 & 4.84 & 0.30 & 0.21 & 0.19 & 0.03 \\
\hline & \multirow{3}{*}{ Zone-B } & 4 & -0.06 & 0.31 & 0.03 & 0.20 & 0.52 & 2.17 & 0.07 & 0.08 & 0.49 & 0.02 \\
\hline & & 5 & -0.26 & 0.10 & 0.29 & -0.12 & 0.90 & 2.21 & 0.40 & 0.10 & 0.02 & 0.00 \\
\hline & & 6 & 0.02 & 0.01 & 0.36 & 0.22 & 0.55 & 0.05 & 0.09 & 0.07 & 0.02 & 0.00 \\
\hline & \multirow{3}{*}{ Zone-C } & 7 & -0.01 & 0.00 & 0.00 & 0.17 & -0.01 & 0.96 & 0.63 & 0.03 & 0.01 & 0.00 \\
\hline & & 8 & -0.33 & 0.03 & 0.86 & -0.13 & 0.77 & 0.10 & 0.21 & 0.04 & 0.00 & 0.01 \\
\hline & & 9 & -0.02 & 0.62 & 0.35 & -0.04 & 0.34 & 0.17 & 0.05 & 0.09 & 0.01 & 0.01 \\
\hline & \multirow{3}{*}{ Zone-D } & 10 & 0.00 & 0.01 & 0.01 & 0.02 & 0.00 & 0.15 & 0.06 & 0.02 & 0.00 & 0.00 \\
\hline & & 11 & -0.05 & 0.06 & -0.03 & 0.14 & 0.03 & 0.17 & 0.09 & 0.04 & 0.01 & 0.01 \\
\hline & & 12 & 0.01 & 0.00 & 0.01 & 0.05 & 0.11 & 0.19 & 0.03 & 0.10 & 0.00 & 0.00 \\
\hline
\end{tabular}


Table 1. Cont.

\begin{tabular}{|c|c|c|c|c|c|c|c|c|c|c|c|c|}
\hline \multirow[b]{2}{*}{ Period } & \multirow[b]{2}{*}{ Zone } & \multirow[b]{2}{*}{ Station No. } & \multicolumn{5}{|c|}{$\begin{array}{l}\text { Temperature Differences Per Unit Depth in the } \\
\text { ND }\left({ }^{\circ} \mathrm{C} \mathrm{m}^{-1}\right)\end{array}$} & \multicolumn{5}{|c|}{$\begin{array}{l}\text { Temperature Differences Per Unit Depth in the } \\
\text { FCG }\left({ }^{\circ} \mathrm{C} \mathrm{m}^{-1}\right)\end{array}$} \\
\hline & & & $\begin{array}{c}0.5 \\
\mathrm{~m}^{-1 / 5} \\
\mathrm{~h}\end{array}$ & $\begin{array}{c}1 / 5 \\
\mathrm{~h}^{-2} / 5 \mathrm{~h}\end{array}$ & $\begin{array}{c}2 / 5 \\
h^{-3} / 5 \mathrm{~h}\end{array}$ & $\begin{array}{c}3 / 5 \\
h^{-4} / 5 \mathrm{~h}\end{array}$ & $\begin{array}{c}4 / 5 \\
\mathrm{~h}^{-0.5} \\
\mathrm{~m} \mathrm{up}\end{array}$ & $\begin{array}{c}0.5 \\
\mathrm{~m}^{-1 / 5} \\
\mathrm{~h}\end{array}$ & $\begin{array}{c}1 / 5 \\
h^{-2} / 5 h\end{array}$ & $\begin{array}{c}2 / 5 \\
h^{-3} / 5 \mathrm{~h}\end{array}$ & $\begin{array}{c}3 / 5 \\
\mathrm{~h}^{-4} / 5 \mathrm{~h}\end{array}$ & $\begin{array}{c}4 / 5 \\
\mathrm{~h}^{-0.5} \\
\mathrm{~m} \mathrm{up}\end{array}$ \\
\hline \multirow{12}{*}{ Ebb Slack } & \multirow{3}{*}{ Zone-A } & 1 & 0.00 & 0.02 & 0.80 & -0.08 & 0.85 & 0.29 & 1.47 & 0.68 & 2.53 & 3.50 \\
\hline & & 2 & 4.00 & -0.55 & 0.17 & 0.80 & 2.13 & 2.02 & 1.16 & 0.50 & 3.59 & 5.74 \\
\hline & & 3 & 5.06 & -0.18 & -0.60 & 2.52 & -1.29 & 0.17 & 0.15 & 2.93 & 2.36 & 3.41 \\
\hline & \multirow{3}{*}{ Zone-B } & 4 & 0.00 & 0.61 & 0.85 & 0.96 & 0.00 & -0.20 & 0.72 & 2.34 & 6.25 & 1.80 \\
\hline & & 5 & 0.22 & -0.07 & 0.19 & 1.92 & -0.06 & -0.56 & -0.59 & -2.25 & 1.00 & 0.68 \\
\hline & & 6 & 8.13 & 0.97 & 0.75 & 0.49 & 0.55 & 0.05 & 0.10 & 0.00 & -0.73 & -0.53 \\
\hline & \multirow{3}{*}{ Zone-C } & 7 & 6.60 & 1.32 & -0.82 & 1.07 & 0.10 & -0.19 & -0.69 & 0.04 & 3.57 & 1.63 \\
\hline & & 8 & 0.04 & 0.03 & 0.28 & 1.36 & 0.24 & 0.09 & -0.13 & -0.26 & -0.08 & 0.23 \\
\hline & & 9 & 0.06 & 0.00 & 0.04 & 1.79 & -4.24 & -0.02 & 0.05 & 0.03 & 0.06 & 0.05 \\
\hline & \multirow{3}{*}{ Zone-D } & 10 & 1.74 & -0.45 & 0.00 & 0.91 & -2.26 & -0.09 & -0.34 & 0.22 & 0.36 & 0.09 \\
\hline & & 11 & -0.06 & 0.19 & 0.07 & -0.01 & -0.06 & 0.02 & 0.03 & 0.02 & 0.01 & 0.01 \\
\hline & & 12 & 0.01 & 0.00 & 0.01 & 0.05 & 0.11 & -0.06 & 0.15 & 0.00 & 0.06 & 0.05 \\
\hline \multirow{12}{*}{ Flood Maximum } & \multirow{3}{*}{ Zone-A } & 1 & -0.12 & 0.07 & -0.11 & -0.03 & 0.02 & 2.39 & 1.37 & 0.01 & 0.05 & 0.19 \\
\hline & & 2 & 0.34 & -0.24 & 0.34 & 0.17 & 1.51 & 1.01 & 2.59 & 0.01 & 0.01 & 0.03 \\
\hline & & 3 & 0.26 & 0.11 & 0.08 & 0.07 & 0.12 & 5.34 & 0.62 & 0.01 & 0.00 & 0.00 \\
\hline & \multirow{3}{*}{ Zone-B } & 4 & 0.53 & 0.19 & 0.24 & 0.17 & 0.05 & 0.28 & 0.30 & -0.06 & 0.19 & 0.13 \\
\hline & & 5 & -0.34 & -0.02 & 0.08 & -0.07 & -0.02 & 5.55 & 0.25 & 0.19 & 0.00 & 0.00 \\
\hline & & 6 & -0.07 & 0.24 & 0.04 & 0.02 & 0.03 & 0.38 & 0.12 & 0.14 & -0.01 & 0.00 \\
\hline & \multirow{3}{*}{ Zone-C } & 7 & -0.12 & 0.28 & 0.16 & 0.10 & 0.19 & 0.03 & 0.33 & 0.14 & 0.01 & -0.08 \\
\hline & & 8 & 0.19 & 0.19 & 0.06 & 0.00 & -0.02 & 0.15 & 0.22 & 0.06 & 0.00 & 0.00 \\
\hline & & 9 & 0.06 & 0.01 & -0.01 & 0.00 & -0.13 & 0.15 & 0.07 & -0.02 & -0.01 & 0.00 \\
\hline & \multirow{3}{*}{ Zone-D } & 10 & 0.01 & 0.04 & 0.06 & 0.01 & 0.01 & 0.17 & 0.02 & 0.04 & 0.00 & 0.00 \\
\hline & & 11 & 0.05 & 0.03 & 0.01 & 0.00 & 0.01 & 0.14 & 0.03 & 0.25 & 0.02 & 0.01 \\
\hline & & 12 & -0.08 & 0.21 & 0.34 & 0.07 & -0.04 & 0.01 & 0.04 & 0.07 & 0.05 & 0.02 \\
\hline
\end{tabular}

As shown in Figure 3a, at flood slack, the vertical water temperatures in Zone-A, Zone-C, and Zone-D in the ND did not show stratification, especially in Zone-A and Zone-D, where the vertical water temperatures were basically the same. However, the stratification patterns in Zone-B were obvious. The thermocline occurred below $4 / 5 \mathrm{~h}$ (water depths of approximately $6 \mathrm{~m}-8 \mathrm{~m}$ ) and the average temperature difference between $4 / 5 \mathrm{~h}$ and $0.5 \mathrm{~m}$ from the seafloor per unit water depth reached $0.70{ }^{\circ} \mathrm{C} \mathrm{m}^{-1}$.

As shown in Figure 3b, the vertical water temperatures in Zone-A and Zone-D in the ND did not show stratification at maximum ebb, and the vertical water temperatures were basically the same. However, the stratification patterns of Zone-B and Zone- $C$ were obvious. The stratification in the former occurred below $1 / 5 \mathrm{~h}$, while the most obvious stratification appeared below $4 / 5 \mathrm{~h}$ (water depths of approximately $4 \mathrm{~m}-7 \mathrm{~m}$ ), and the average temperature difference between $0.5 \mathrm{~m}$ and $1 / 5 \mathrm{~h}$ water layers per unit water depth reached $0.66{ }^{\circ} \mathrm{C} \mathrm{m}^{-1}$; in contrast, the stratification in the latter occurred below $1 / 5 \mathrm{~h}$, while the most obvious stratification appeared at depths of $2 / 5 \mathrm{~h}-3 / 5 \mathrm{~h}$ (water depths of approximately $1 \mathrm{~m}-3 \mathrm{~m}$ ), and the average temperature difference per unit water depth s reached $0.61{ }^{\circ} \mathrm{C} \mathrm{m}^{-1}$ between these two water layer.

As shown in Figure 3c, the vertical water temperatures in Zone-D in the ND did not exhibit stratification at ebb slack, and the vertical water temperatures were basically the same, whereas the stratification patterns in Zone-A, Zone-B, and Zone-C were obvious, and the thermocline was basically distributed throughout the entire water column in these three zones.

As shown in Figure 3d, the water temperatures at most stations in Zone-C and Zone-D in the ND did not display stratification at maximum flood. In contrast, stratification phenomena appeared at most stations in Zone-A and Zone-B; significant stratification occurred below $0.5 \mathrm{~m}$ to $1 / 5 \mathrm{~h}$ at most stations in these two zones.

As shown in Figure 3e, at flood slack, stratification occurred from $0.5 \mathrm{~m}$ to $2 / 5 \mathrm{~h}$ and $3 / 5 \mathrm{~h}$ to $4 / 5 \mathrm{~h}$ in most stations in Zone-A in the FCG, and the most significant stratification appeared below $0.5 \mathrm{~m}$ to 
$1 / 5 \mathrm{~h}$ and the average temperature difference per unit water depth between these two water layers reached $1.91^{\circ} \mathrm{C} \mathrm{m}^{-1}$ (water depths of approximately $0.5 \mathrm{~m}-2 \mathrm{~m}$ ). Stratification occurred below $0.5 \mathrm{~m}$ to $1 / 5 \mathrm{~h}$ and $3 / 5 \mathrm{~h}$ to $4 / 5 \mathrm{~h}$ at most stations in Zone-B and Zone-C, while the most significant stratification appeared below $3 / 5 \mathrm{~h}$ to $4 / 5 \mathrm{~h}$ and the average temperature difference per unit water depth between was $0.38^{\circ} \mathrm{C} \mathrm{m}^{-1}$ (water depths of approximately $4 \mathrm{~m}-8 \mathrm{~m}$ ) in Zone-B and $0.26^{\circ} \mathrm{C} \mathrm{m}^{-1}$ (water depths of approximately $3 \mathrm{~m}-11 \mathrm{~m}$ ) in Zone-C.

As shown in Figure 3f, stratification occurred below $0.5 \mathrm{~m}$ to $1 / 5 \mathrm{~h}$ and $2 / 5 \mathrm{~h}$ to $3 / 5 \mathrm{~h}$ at most stations in Zone-A in the FCG at maximum ebb, and the most significant stratification appeared below $0.5 \mathrm{~m}$ to $1 / 5 \mathrm{~h}$ and the average temperature difference per unit water depth between $0.5 \mathrm{~m}$ to $1 / 5 \mathrm{~h}$ was $5.44^{\circ} \mathrm{C} \mathrm{m}^{-1}$ (water depths of approximately $0.5 \mathrm{~m}-2 \mathrm{~m}$ ). Most of the thermocline phenomena in Zone-B occurred at depths from $0.5 \mathrm{~m}$ to $1 / 5 \mathrm{~h}$ and occurred at depths from $0.5 \mathrm{~m}$ to $2 / 5 \mathrm{~h}$ in Zone-C. The average temperature difference per unit water depth between water layers with most of the thermocline phenomena in Zone-B was $1.47^{\circ} \mathrm{C} \mathrm{m}^{-1}$ (water depths of approximately $0.5 \mathrm{~m}-2 \mathrm{~m}$ ) and in Zone-C was $0.33^{\circ} \mathrm{C} \mathrm{m}^{-1}$ (water depths of approximately $0.5 \mathrm{~m}-3 \mathrm{~m}$ ). There was no stratification in Zone-D.

As shown in Figure $3 g$, the ebb slack thermocline was basically distributed throughout the whole water column in Zone-A in the FCG. At most stations in Zone-A, the thermocline occurred in the bottom layer at water depths from $3 / 5 \mathrm{~h}$ to $0.5 \mathrm{~m}$ above the bottom (water depths of approximately $1 \mathrm{~m}-4 \mathrm{~m}$ ). The average DTPD in Zone-A reached $1.8^{\circ} \mathrm{C} \mathrm{m}^{-1}$. The highest temperature at all the stations in Zone-B was not found at the surface; most of the high-temperature locations were distributed below water depths of $4 / 5 \mathrm{~h}$ to $0.5 \mathrm{~m}$ above the bottom. The thermocline was basically distributed throughout the whole water column in Zone-B and most of the significant stratification appeared at water depths below $1 / 5 \mathrm{~h}$ to $0.5 \mathrm{~m}$ above the bottom at most stations. Similarly, the highest temperature at all the stations in Zone-C was not found in the surface layer, and the stratification characteristics in Zone-C were not clear. In Zone-D, there was no thermocline, except at station No. 10, which had a thermocline below $1 / 5 \mathrm{~h}$ to $4 / 5 \mathrm{~h}$.

As shown in Figure $3 \mathrm{~h}$, stratification occurred below $0.5 \mathrm{~m}$ to $2 / 5 \mathrm{~h}$ at all stations in Zone-A and Zone-B in the FCG at maximum flood. The average temperature differences between these two layers per unit water depth in Zone-A and Zone-B were $2.03^{\circ} \mathrm{C} \mathrm{m}^{-1}$ (water depths of approximately $0.5 \mathrm{~m}-2.5 \mathrm{~m}$ ) and $0.89^{\circ} \mathrm{C} \mathrm{m}^{-1}$ (water depths of approximately $0.5 \mathrm{~m}-3.5 \mathrm{~m}$ ), respectively. Likewise, stratification occurred below $0.5 \mathrm{~m}$ to $2 / 5 \mathrm{~h}$ at most of the stations in Zone-C, with an average temperature difference per unit water depth of $0.21{ }^{\circ} \mathrm{C} \mathrm{m}^{-1}$ (water depths of approximately $1 \mathrm{~m}-3 \mathrm{~m}$ ). Finally, there was no thermocline except at station No. 11, which had a slight thermocline below depths from $2 / 5 \mathrm{~h}$ to $3 / 5 \mathrm{~h}$ in Zone-D.

\section{Discussion}

\subsection{Comparison between the SSTs and SBTs in Sea Areas with Different Tidal Dynamics}

The SSTs and SBTs of the four zones in the two study areas decreased with increasing distance from the outlet from the comparison of the two study areas. In the ND, little difference between the SSTs and SBTs was observed within $0.5 \mathrm{~km}$ from the outlet, whereas large differences appeared between the SSTs and SBTs $0.5 \mathrm{~km}$ away from the outlet. There were large differences between the SSTs and SBTs at all four tidal times in the four zones in the FCG. The SSTs and SBTs of the four groups were higher at ebb slack and lower at flood slack and maximum flood with regard to different tidal times.

The DTPDs at the four tidal times in the ND decreased in the following order: Zone- $\mathrm{B}>$ Zone- $\mathrm{C}>$ Zone-A $>$ Zone-D; the decreasing order in the FCG was Zone-A $>$ Zone-B $>$ Zone-C $>$ Zone-D. At the different tidal times, in all the zones, except for Zone-D in the ND and Zone-C and Zone-D in the FCG, in which the DTPD changed little among the four tidal times, the maximum DTPDs appeared at ebb slack, whereas the minimum DTPDs appeared at flood slack and maximum flood.

The SSTs of Zone-A, Zone-B and Zone-C in the ND increased by $3.22{ }^{\circ} \mathrm{C}, 1.42{ }^{\circ} \mathrm{C}$, and $0.71{ }^{\circ} \mathrm{C}$, respectively, and the SBTs of Zone-A, Zone-B and Zone-C increased by $2.86^{\circ} \mathrm{C}, 0.54{ }^{\circ} \mathrm{C}$, and $0.24{ }^{\circ} \mathrm{C}$, 
respectively, in addition to the average temperatures at the four tidal times in the four zones, with Zone-D as a reference. Likewise, with Zone-D as a reference, the SSTs of Zone-A, Zone-B and Zone-C in the FCG increased by $3.52{ }^{\circ} \mathrm{C}, 1.08^{\circ} \mathrm{C}$ and $0.22^{\circ} \mathrm{C}$, respectively, while the SBTs of Zone-A, Zone-B, and Zone-C increased by $0.47^{\circ} \mathrm{C}, 0.40^{\circ} \mathrm{C}$, and $0.14^{\circ} \mathrm{C}$, respectively. The SST increase in Zone-A in the FCG was larger than that in the ND; similarly, the other SST and SBT increases in the ND were larger than those in the FCG.

As discussed in Section 3.1, the thermal discharge in the ND had little influence in Zone-D, while it had greater impacts on the SSTs and SBTs in the other three zones; that is, the thermal discharge influenced the surface and the bottom seawater within $3 \mathrm{~km}$ from the outlet. In contrast, the thermal discharge in the FCG had little influence in Zone- $C$ and Zone-D, while it had greater impacts on only the SSTs in Zone-A and Zone-B; that is, the thermal discharge only influenced the surface seawater (rather than the bottom seawater) within $1 \mathrm{~km}$ from the outlet. The increase in temperature in the FCG was larger than that in the ND at distances of $0 \mathrm{~km}$ to $0.5 \mathrm{~km}$ from the outlet. This difference is mainly because the FCG is located in the South China Sea, where the tidal dynamics are relatively weak, while the ND is located in the East China Sea, where the tidal dynamics are relatively strong. In addition, the ND is located on the Fujian coast, where upwelling occurs, and strong tidal dynamics and upwelling are both beneficial for the vertical mixing of seawater [33]. Therefore, the vertical mixing that was near the outlet in the ND was sufficient; consequently, warm water could quickly diffuse to the bottom seawater, while it was difficult for the warm water near the outlet in the FCG to reach the bottom seawater and, as a result, most of the warm water diffused within the surface seawater.

With regard to different tidal times, the SSTs and SBTs in the four zones were higher at ebb slack and lower at flood slack and maximum flood. The DTPD reached its maximum at ebb slack and its minimum at flood slack and maximum flood. It was inferred that thermal discharge mostly affected the SSTs and SBTs at ebb slack, which resulted in the largest DTPD between the surface and bottom layers and the most obvious stratification pattern. This result was mainly because of the lowest water level at ebb slack, which had the weakest dilution effect on the thermal discharge, thus benefiting the diffusion of the thermal discharge on the surface and throughout the vertical column.

\subsection{Comparisons between the Positions and Extents of the Thermoclines in Sea Areas with Different Tidal Dynamics}

The thermocline clearly decreased with increasing distance from the outlet at any tidal time if stratification was present with regard to the depth of the thermocline in each zone in the ND. This result occurred because the warm water that was discharged to the surface from the outlet gradually diffused downward. Zone-A did not exhibit a stratification phenomenon at flood slack or maximum flood; moreover, although Zone-A appeared to stratify at ebb slack and maximum ebb, the extent of stratification was not as significant as that in Zone-B or Zone-C. This result indicates that the warm water in the ND was uniformly vertically mixed at distances of $0 \mathrm{~km}$ to $0.5 \mathrm{~km}$ from the outlet. From a comparison among the four tidal times, the average temperature in the three zones affected by thermal discharge gradually increased from flood slack to ebb slack until reaching the maximum value; then, the average temperature gradually decreased until flood slack, when it reached the lowest average temperature. In addition, the thermocline mostly appeared in the upper seawater layers during flood tide (from ebb slack to flood slack) and in the lower water layers during ebb tide (from flood slack to ebb slack), which is consistent with the research of Lin et al. [20]. Moreover, we found that the depth of the thermocline gradually moved upward from flood slack $\rightarrow$ maximum ebb $\rightarrow$ ebb slack; in contrast, the depth of the thermocline gradually moved downward from ebb slack to maximum flood.

The SSTs at most stations in Zone-D in the FCG were slightly larger than the SBTs. Furthermore, there was no stratification at most stations in Zone-D. Regarding the depth of the thermocline in each zone, except at ebb slack, the depth of the thermocline increased with distance from the outlet at all times, which contrasts with the results in the ND. From a comparison among the four tidal times, the average temperature in the three zones affected by thermal discharge gradually increased 
from flood slack to ebb slack until reaching the maximum value; then, the average temperature then gradually decreased until flood slack, when the lowest average temperature occurred. In addition, the thermocline mostly appeared in the upper seawater layers during any tidal time, except ebb slack. Moreover, we found that the depth of the thermocline gradually moved upward from flood slack $\rightarrow$ maximum ebb $\rightarrow$ ebb slack; in contrast, the depth of the thermocline gradually moved upward from ebb slack to maximum flood, which is different from the corresponding result in the ND.

We can draw the following conclusions based on these comparisons of the temperature differences between the surface and bottom layers and the locations and extents of the thermoclines in the two study areas:

(1) The depth of the thermocline gradually moved upward with increasing distance from the outlet. In the ND, no stratification phenomenon appeared at flood slack or maximum flood within 0.5 $\mathrm{km}$ from the outlet. Moreover, although there was no stratification phenomenon at ebb slack and maximum ebb within $0.5 \mathrm{~km}$ from the outlet, the extent of stratification was not as significant as that within $0.5 \mathrm{~km}$ to $3.0 \mathrm{~km}$ from the outlet. Except during ebb slack, the depth of the thermocline increased with the distance from the outlet, which contrasts with the result in the ND. The ND is located in the East China Sea and it has strong tidal dynamics that result in uniform vertical mixing. Therefore, the SSTs and the SBTs near the outlet both significantly increased, which is why there was no stratification or there was only weak stratification near the outlet in the ND. This result is consistent with both the study by Zhang [25] in Longkou at the junction of the Bohai Sea and the Yellow Sea and the study by Zhang [25] in Luoyuan Bay in the East China Sea. In contrast, the FCG is located in the South China Sea, where the tidal dynamics are weak and vertical mixing is poor; thus, it takes warm water a longer time to undergo downward mixing. Therefore, the thermocline appeared at deeper water depths as the distance from the outlet increased, which is consistent with the study of Zhou [34] in Daya Bay in the South China Sea. The extent of stratification in the FCG was larger than that in the ND because of the poor downward mixing ability of warm water in the FCG; additionally, the average temperature difference was $5.44^{\circ} \mathrm{C} \mathrm{m}^{-1}$ and the maximum temperature difference was $7.47^{\circ} \mathrm{C} \mathrm{m}^{-1}$ at water depths ranging from $0.5 \mathrm{~m}$ to $1 / 5 \mathrm{~h}$.

(2) From the comparison among the four tidal times, the average temperature of the seawater affected by the thermal discharge was the lowest at flood slack and highest at ebb slack. The water level is lowest at ebb slack and the dilution effect on the thermal discharge is weaker; therefore, the average seawater temperature was the highest at ebb slack. The water level is highest at flood slack and the dilution effect on the thermal discharge is greater; therefore, the average seawater temperature was lowest at flood slack. In the ND, the thermocline mostly appeared in the upper seawater layers during flood tide and in the lower water layers during ebb tide, while, in the FCG, the thermocline mostly appeared in the upper seawater layers, except during ebb slack. The depth of the thermocline gradually moved upward from flood slack $\rightarrow$ maximum ebb $\rightarrow$ ebb slack; in contrast, the depth of the thermocline gradually moved downward from ebb slack to maximum flood, which contrasts with the patterns found in the FCG. This difference is mainly due to the strong tidal dynamics and strong vertical mixing in the ND. The water depth was greater at flood slack, and most of the water column could be fully mixed with the warm water; only the bottom water did not mix evenly, so the thermocline appeared in the lower layer. At ebb tide, the water depth gradually decreased, which was conducive to the diffusion of warm water downward from the surface. Therefore, the thermocline appeared throughout the whole water column, and the thermocline gradually moved upward. At flood tide, the water depth gradually increased and it was not conducive to the diffusion of warm water from the surface; thus, the thermocline moved downward because of the downward diffusion of warm water. In the FCG, the tidal dynamics are weak, and the diffusion of thermal discharge is weak in the vertical direction. At the same time, the FCG is located in the South China Sea, where a weak stratification phenomenon appears in summer, which confines the warm thermal plume within 
the upper few meters of water. The discharge of warm water further increases the surface water temperature, which enhances stratification [37]. Therefore, the warm water usually diffused in the surface layer, and the most serious stratification occurred at depths of $0.5 \mathrm{~m}^{-1} / 5 \mathrm{~h}$, except at ebb slack. The thermal plume can only reach the bottom at ebb slack, when the depth is relatively shallow and the conditions are most conducive to vertical diffusion. Generally, the thermocline caused by thermal discharge is distributed at water depths shallower than $7 \mathrm{~m}$, which is consistent with the results of Wang et al. [36], Cui [23], Zhang et al. [21], and Han [39], who studied CNATPP in China, and Suh et al. [35], who studied CNATPP in Korea.

\section{Conclusions}

(1) The thermal discharge influenced the sea within $3 \mathrm{~km}$ from the outlet, whereas the thermal discharge had little impact on the sea area beyond $3 \mathrm{~km}$ from the outlet.

(2) In the East China Sea, which has strong tidal dynamics, vertical mixing is sufficient in the sea area near the outlet; therefore, the most significant stratification occurred $0.5 \mathrm{~km}-1.0 \mathrm{~km}$ from the outlet; however, the degree of stratification decreased with increasing distance from the outlet, and the most significant stratification occurred near the outlet in the South China Sea, which has weak tidal dynamics.

(3) In the East China Sea (with strong tidal dynamics), the thermocline primarily appeared in the upper seawater layers during flood tide (from ebb slack to flood slack) and in the lower water layers during ebb tide (from flood slack to ebb slack). Moreover, the depth of the thermocline during ebb tide gradually moved upward, while that during flood tide gradually moved downward. In the South China Sea (with weak tidal dynamics), the thermocline mostly appeared in the upper seawater layer during any tidal time, except ebb slack. Moreover, the depth of the thermocline during ebb tide gradually moved downward, while that during flood tide gradually moved upward, which contrasts with the results in the ND.

(4) Thermal discharge can induce stratification, especially in the South China Sea, where the tidal dynamics are poor and weak stratification is sometimes already present. The thermocline that was caused by thermal discharge on the surface mostly occurred at water depths shallower than $7 \mathrm{~m}$.

Through this research, we understand some characteristics of thermocline caused by thermal discharge in sea areas with different tidal dynamics. The increase in seawater temperature could cause seawater to stratify, which influences the foraging environment of marine organisms. This study can provide a theoretical basis for the study of how thermal discharge affects the abundance and community structure of marine organisms through this way.

Author Contributions: Validation, F.H., J.L. and B.Z.; investigation, B.Z.; writing —original draft preparation, J.L.; writing-review and editing, J.L.; supervision, F.H.; project administration, F.H.; funding acquisition, J.L.

Funding: This research was funded by Jie Lin, grant number No. 2017016.

Conflicts of Interest: The authors declare no conflict of interest.

\section{References}

1. Briand, F.J.P. Effects of power-plant cooling systems on marine phytoplankton. Mar. Biol. 1975, 33, 135-146.

2. Brook, A.J.; Baker, A.L. Chlorination at power plants: Impact on phytoplankton productivity. Science 1972, 176, 1414-1415. [CrossRef] [PubMed]

3. Li, X.Y.; Li, B.; Sun, X.L. Effects of a coastal power plant thermal discharge on phytoplankton community structure in Zhanjiang Bay, China. Mar. Pollut. Bull. 2014, 81, 210-217. [CrossRef] [PubMed]

4. Jiang, Z.B.; Liao, Y.B.; Liu, J.J.; Shou, L.; Chen, Q.Z.; Yan, X.J.; Zhu, F.H.; Zeng, J.N. Effects of fish farming on phytoplankton community under the thermal stress caused by a power plant in a eutrophic, semi-enclosed bay: Induce toxic dinoflagellate (Prorocentrum minimum) blooms in cold seasons. Mar. Pollut. Bull. 2013, 76, 315-324. 
5. Chew, L.L.; Chong, V.C.; Wong, R.C.; Lehette, P.; Ng, C.C.; Loh, K.H. Three decades of sea water abstraction by Kapar power plant (Malaysia): What impacts on tropical zooplankton community? Mar. Pollut. Bull. 2015, 101, 69-84.

6. Li, G.G.; Shi, H.W.; Xu, Z.H. Path analysis of thermal discharge near power plant on estuarine copepods community structure in Xiangshan bay in summer. Mar. Environ. Sci. 2017, 36, 706-711.

7. Vandysh, O.I. The effect of thermal flow of large power facilities on zooplankton community under subarctic conditions. Water Resour. 2009, 36, 310-318. [CrossRef]

8. Worthington, T.A.; Shaw, P.J.; Daffern, J.R.; Langford, T.E.L. The effects of a thermal discharge on the macroinvertebrate community of a large British river: Implications for climate change. Hydrobiologia 2015, 753, 81-95. [CrossRef]

9. Durance, I.; Ormerod, S.J. Climate change effects on upland stream macroinvertebrates over a 25-year period. Glob. Chang. Biol. 2007, 13, 942-957. [CrossRef]

10. Jiang, Z.P. The Distribution Pattern of Fish in the Sea Area of Thermal Discharge of Qinshan Nuclear Plan. Ph.D. Thesis, Shanghai Ocean University, Shanghai, China, 2016.

11. Teixeira, T.P.; Neves, L.M.; Araújo, F.G. Effects of a nuclear power plant thermal discharge on habitat complexity and fish community structure in Ilha Grande Bay, Brazil. Mar. Environ. Res. 2009, 68, 188-195.

12. Reutter, J.M.; Herdendorf, C.E. Thermal discharge from a nuclear power plant: Predicted effects on Lake Erie fish. Ohio J. Sci. 1976, 76, 39-45.

13. Wei, X.Y.; Wang, Y.C.; Zhang, Q.; Dang, Y.Q.; Xiong, X.W.; Shang, Z.R. Review of the impact assessment of thermal discharges from power plants on aquatic biota. J. Hydroecol. 2018, 39, 1-10.

14. Shiers, P.F.; Marks, D.H. Thermal Pollution Abatement Evaluation Model for Power Plant Siting; MIT Energy Lab.: Boston, MA, USA, 1973.

15. Zhang, A.L.; Wang, S.W.; Zhao, Y.J.; Yuan, J. Analysis of Key Issues in Environmental Impact Assessment of Thermal Discharge from Coastal Nuclear Power Plant. Environ. Impact Assess. 2015, 37, 57-60.

16. Zeng, J.N. Ecological Effect by Thermal Discharged Water from Subtropical Coastal Power Plants. Ph.D. Thesis, Zhejiang University, Hangzhou, China, 2008.

17. Poornima, E.H.; Rajadurai, M.; Rao, T.S.; Anupkumarb, B.; Rajamohanb, R.; Narasimhanb, S.V.; Raoa, V.N.R.; Venugopalanb, V.P. Impact of thermal discharge from a tropical coastal power plant on phytoplankton. J. Therm. Biol. 2005, 30, 307-316. [CrossRef]

18. Han, X. Prelimimary Study on Damage Assessment and Ecological Compensation of Coastal Power Plant Thermal Discharge Pollution. Ph.D. Thesis, East China Normal University, Shanghai, China, 2012.

19. Yin, J.P.; Wang, Y.S.; Xu, J.R.; Sun, C.C.; Zhang, F.Q. Seasonal thermocline in the Daya Bay and its influence on the environmental factors of seawater. Mar. Sci. Bull. 2006, 25, 1-8.

20. Lin, J.; Zou, X.Q.; Huang, F.M. Effects of the thermal discharge from an offshore power plant on plankton and macrobenthic communities in subtropical China. Mar. Pollut. Bull. 2018, 131, 106-114. [CrossRef]

21. Zhang, Z.J.; Li, Y.Q.; Hao, R.X.; Han, L.J. Application of ECOMSED model in calculation of power plant thermal discharge of tidal water. Water Resour. Power 2015, 33, 55-61.

22. Wu, Y.F.; Zhu, J.R. Numerical simulation of transport and diffusion of thermal discharge water from the power plants in the Changjiang estuary. J. East China Norm. Univ. 2017, 2, 127-137.

23. Cui, D. 3D Numerical Simulation on Thermal Discharge of Coastal Thermal Power Plant; Yangtze River Scientific Research Institute: Wuhan, China, 2008.

24. Zhu, Z.C. Numerical Simulation of Three-Dimensional Seawater Temperature Field in Meizhou Bay Based on Fvcom and Controlled Analysis with Observational Material; First Institute of Oceanography, State Oceanic Administration: Qingdao, China, 2014.

25. Zhang, W.J. Three-Dimensional Numerical Simulation of Cooling Water in Longkou Northern Waters; First Institute of Oceanography, State Oceanic Administration: Qingdao, China, 2015.

26. Raithby, G.D.; Elliott, R.V.; Hutchinson, B.R. Prediction of three-dimensional thermal discharge flows. J. Hydraul. Eng. 1988, 114, 720-737. [CrossRef]

27. Salgueiro, D.V.; de Pablo, H.; Neves, R.; Mateus, M. Modelling the thermal effluent of a near coast power plant (Sines, Portugal). Rev. Gest. Costeira Integr. 2015, 15, 533-544. [CrossRef]

28. Råman, V.L.; Wuest, A.; Bouffard, D. Physical effects of thermal pollution in lakes. Water Resour. Res. 2017, 53, 3968-3987. [CrossRef] 
29. Kirillin, G.; Shatwell, T.; Kasprzak, P. Consequences of thermal pollution from a nuclear plant on lake temperature and mixing regime. J. Hydrol. 2013, 496, 47-56. [CrossRef]

30. Roenunich, D.; MdGowan, J. Climate warming and the decline of zooplankton in the Califomia Current. Science 1995, 267, 1324-1326.

31. Zhao, L.L.; Zhu, G.W.; Chen, Y.F.; Li, W.; Zhu, M.Y.; Yao, X.; Cai, L.L. Thermal stratification and its influence factors in a large-sized and shallow Lake Taihu. Adv. Water Sci. 2011, 22, 844-850.

32. Rao, R.R.; Sivakumar, R. Seasonal variability of near-surface isothermal layer and thermocline characteristics of the Tropical Indian Ocean. Meteorol. Atmos. Phys. 1996, 61, 201-212. [CrossRef]

33. Feng, S.Z.; Li, F.Q.; Li, S.Q. Introduction to Ocean Science; Higher Education Press: Beijing, China, 2015; pp. 484-486.

34. Zhou, Q.J. Study on Thermal Pollution in Daya Bay. Ph.D. Thesis, East China Normal University, Shanghai, China, 2007.

35. Suh, S.W. A hybrid near-field/far-field thermal discharge model for coastal areas. Mar. Pollut. Bull. 2001, 43, 225-233. [CrossRef]

36. Wang, X.; Zhang, A.J.; Geng, X.; Zheng, L.; Liu, S.H. Study of impact of the discharged cooling water from Huangdao coastal power plant on the thermohaline distribution. Mar. Sci. Bull. 2013, 32, 389-394.

37. Tang, D.L.; Kester, D.R.; Wang, Z.D.; Lian, J.S.; Kawamura, H. AVHRR satellite remote sensing and shipboard measurements of the thermal plume from the Daya Bay, nuclear power station, China. Remote Sens. Environ. 2003, 84, 506-515. [CrossRef]

38. Tang, S.M.; Yan, Y.; Chen, B. Impacts of thermal effluent on the phytoplankton community structures nearby Dayawan Nuclear Power Station in spring and summer. J. Appl. Oceanogr. 2013, 32, 373-382.

39. Han, L.J. Three-Dimensional Numerical Simulation on Thermal Discharge of Coastal Power Plant. Ph.D. Thesis, Taiyuan University of Technology, Taiyuan, China, 2014.

(C) 2019 by the authors. Licensee MDPI, Basel, Switzerland. This article is an open access article distributed under the terms and conditions of the Creative Commons Attribution (CC BY) license (http://creativecommons.org/licenses/by/4.0/). 